\title{
Particulate matters collected from ceramic factories in Lampang Province affecting rat lungs*
}

\author{
Duriya FONGMOON ${ }^{1}$, Surathat PONGNIKORN ${ }^{1}$, Aphiruk CHAISENA ${ }^{2}$, Sitthichai IAMSAARD ${ }^{\dagger+3}$ \\ ( ${ }^{1}$ Department of Medical Services, Lampang Cancer Hospital, Ministry of Public Health, Lampang 52000, Thailand) \\ ( ${ }^{2}$ Department of Applied Chemistry and Centre for Innovation in Chemistry, Faculty of Science, \\ Lampang Rajabhat University, Lampang 52100, Thailand) \\ ( ${ }^{3}$ Department of Anatomy and Integrative Complementary Alternative Medicine (ICAM) Research and Development Group, \\ Faculty of Medicine, Khon Kaen University, Khon Kaen 40002, Thailand) \\ 'E-mail: iamsaard_sitt@yahoo.com
}

Received Mar. 1, 2013; Revision accepted July 12, 2013; Crosschecked Dec. 25, 2013

\begin{abstract}
Background: Lung cancer ranks as the fifth largest of all cancer cases in Thailand. However, it is the first leading cancer in the northern part of Thailand (data from 2003-2007). There are several predisposing causes that lead to lung cancer and one important inducement is particulate matters (PMs). Lampang Province in Thailand is famous for the ceramic industry, where there are over 200 ceramic industrial factories. PMs are produced during the ceramic manufacturing process and spread throughout all of the working areas. It is very possible that workers could directly inhale PM-contaminated air during working hours. Objective: This study focuses on the toxic effects of PMs collected from ceramic factories on genes and lungs of rats. Methods: PMs collected from six ceramic factories in Lampang Province were extracted using dimethyl sulfoxide (DMSO). The inductively coupled plasma mass spectrometry (ICP-MS) and inductively coupled plasma optical emission spectrometry (ICP-OES) were used to analyze the chemical elements at lower and higher concentrations, respectively. Then, the toxicity of PMs on the genes was examined by the Ames test, and subsequently, the effect of PMs on DNA was examined by quantifying the amount of 8-hydroxy-2'-deoxyguanosine (8-OHdG). Finally, the toxicity of the PMs on rat's lungs was examined by histology. Results: As chemical elements of lower concentrations, cadmium, chromium, nickel, copper, and lead were detected by ICP-MS. As chemical elements of higher concentrations, manganese, magnesium, zinc, iron, potassium, calcium, and sodium were detected by ICP-OES. No mutagenicity in Salmonella typhimurium was found in the PM extracts from all six factories by utilizing the Ames test. In the histological study, the reduction in spaces of alveolar ducts and sacs, and terminal bronchioles, the thickening of interstitial connective tissues were noted by PM extracts in high amounts $(100$ and $350 \mu \mathrm{g})$. Female rats were more sensitive to PM extracts than males in terms of their pulmonary damages. Conclusions: PMs were not mutagenic to $S$. typhimurium but can damage the lung tissue of rats.
\end{abstract}

Key words: Particulate matter (PM), Ceramic factory, Lampang Province, Rat lung doi:10.1631/jzus.B1300058 Document code: A CLC number: X513

\section{Introduction}

The Lampang Cancer Center (LCC) is situated in Lampang, a province in the northern part of

\footnotetext{
¿ Corresponding author

* Project supported by the Oncological Society of Thailand under the Royal Patronage of Her Majesty the Queen (No. RE53006)

(C) Zhejiang University and Springer-Verlag Berlin Heidelberg 2014
}

Thailand. In this center, data have recently been accumulated, indicating that the cancer incidence and mortality rate have been increasing. Newly diagnosed cancer patients in the LCC have increased from 2439 to 3435 cases in 2003-2007 (Raunroadroong et al., 2009). The leading cancers in Lampang are lung, liver, and colorectal cancers in males, and lung, breast, and cervix cancers in females. Epidemiologic data show that during 2003-2007, 40872 male and 44190 
female lung cancer patients have been registered in the northern part of Thailand, where the lung cancer incidence rate is much higher than that in other places in Thailand.

Lampang is famous for its ceramic industry, where there are approximately 200 ceramic factories. The population of this province is about 700000 and about 150000 of them work in the ceramic factories. The raw material utilized in the ceramic industry is kaolin, which can be easily distributed as forms of particulate matters (PMs) or dusts throughout the factories during the processing of ceramic wares. The factory is usually divided into two parts, office and production areas, separated from each other by walls. The production area usually has a roof but it has no partition between departments. Therefore, PMs can easily spread to all areas of the factories and the workers in the ceramic factories have a very high chance of being regularly exposed to PMs. It is a well known fact that PMs are composed of two groups with an aerodynamic diameter of $<10 \mu \mathrm{m}$ (PM10) and $<2.5 \mu \mathrm{m}$ (PM2.5); they constitute a significant threat to human health (Lauer et al., 2009). PM2.5 particles can penetrate deep into the alveolar sacs of the lung (Mantecca et al., 2010). Consequently, it is possible that these particles can be accumulated throughout the respiratory system and thus cause increased hospital admissions for the workers, compared with other people who live near the factories, through chronic respiratory symptoms and lung diseases. This possibility may be a cause for the fact that the lung cancer incidence rate in Lampang is the highest in Thailand. In view of this situation, an attempt to examine the level of PMs in ceramic factories was made and its effects on gene mutation (bacterial model) and lung histology in rats were addressed.

\section{Materials and methods}

\subsection{Sample collection and PM level measurement}

Particle samples were collected by pre-weighed Teflon-impregnated glass fiber filters in drawing air at a constant flow rate. The samplers are battery operated and can run unattended for eight consecutive hours (working hours per worker per day). The filters and batteries were exchanged once a day in the field and the particles were collected in a tube of $37 \mathrm{~mm}$ in length, having pores of $0.5 \mu \mathrm{m}$ in size. The Teflon-impregnated glass fiber filters were obtained from SKC Inc., USA. Each filter was carefully transferred from the filter holder into a clean, labeled, and self-sealing plastic box after sampling. The mass of PM associated with these filters was determined on a six places of gram balance which permitted the measurement of particle concentrations down to $5 \mu \mathrm{g} / \mathrm{m}^{3}$.

The Ministry of Industry of Thailand categorizes factories into three groups based on the number of employees: large (>500), medium (100-500), and small $(<100)$. From a total of 200 factories, six (two from each category) were randomly selected and requested for cooperation as follows: factory $\mathrm{A}, 1125$ employees; factory B, 870 employees; factory C, 266 employees; factory D, 483 employees; factory E, 64 employees; and, factory F, 66 employees.

\subsection{Sample extraction}

A stainless steel scissor was used to cut the filters into small pieces. The pieces of filter were then placed in $200 \mathrm{ml}$ of dichloromethane and sonicated in an ultrasonic bath for $15 \mathrm{~min}$. The extract was filtered through Whatman No. 41 filter paper. Then, water was removed by adding to the sample some anhydrous sodium sulfate. The sonication was repeated two more times with $100 \mathrm{ml}$ of dichloromethane and the beakers and funnels were rinsed with dichloromethane after subsequent filtration. The evaporation of the extract was done using a vacuum rotary evaporation at $35^{\circ} \mathrm{C}$ until it was nearly dried. For mutation assays, $8 \mathrm{~h}$ of filler samples were collected in a 1-month period and pooled together in order to obtain sufficient extractable material. The residue was resolved in $1 \mathrm{ml}$ dimethyl sulfoxide (DMSO) and the sterile solution was obtained after passing through a Milipore filter membrane. This sterile solution was used in a Salmonella mutation test (Vinitketkumnuen et al., 2002). The lightsensitive extracts were stored in a dark area at $4{ }^{\circ} \mathrm{C}$ before use.

\subsection{Elemental analysis of PM extracts}

PM extracts $(0.5 \mathrm{~g})$ were digested using a microware (Berghof, speed wave MWS-2 model) and then were added with concentrate $\mathrm{HNO}_{3} 10 \mathrm{ml}$. The 
digested PM extracts were incubated at $170{ }^{\circ} \mathrm{C}$ for $10 \mathrm{~min}$. After that, they were added to $100 \mathrm{ml}$ of distilled water before analysis by an inductively coupled plasma-atomic emission spectrometer (ICPAES). To analyze the low-concentration chemical elements, an ICP-mass spectrometry (ICP-MS) (Perkin Elmer, ELAN DRC II model) was used, whereas high-concentration chemical elements were analyzed by an ICP-optical emission spectrometry (ICP-OES) (Perlein Elmer, Optima 5300 DV model).

\subsection{Salmonella mutation assay}

The Ames test was conducted to demonstrate the genotoxicity of airbone PM extracts using TA100 as a tester strain with metabolic (S9 mix) activation (Maron and Ames, 1983; Tokiwa et al., 1992; Vinitketkumnuen et al., 2002). The tester strain was supplied by Prof. Taijiro MATSUSHIMA (JapanBioassay Research Center, Kanagawa, Japan). The bacteria were archived in $-80^{\circ} \mathrm{C}$ and they were cultured at $37{ }^{\circ} \mathrm{C}$ for $14 \mathrm{~h}$ in an oxiod nutrient broth before use. The overnight culture was estimated to contain $2 \times 10^{9}$ cells $/ \mathrm{ml}$. Totally $0.05 \mathrm{ml}$ of sample extract and $0.05 \mathrm{ml}$ of $0.2 \mathrm{~mol} / \mathrm{L}$ phosphate buffer (pH 7.4) were added to a sterilized capped culture tube. To prepare indirect acting mutagens, the $0.5 \mathrm{ml}$ of S9 mix was added together with the $0.05 \mathrm{ml} \mathrm{sam}$ ple extract in a sterilized capped culture tube. After that, $0.1 \mathrm{ml}$ of overnight culture of the tester strain was added to these culture tubes, respectively, and these mixtures were pre-incubated at $30{ }^{\circ} \mathrm{C}$ for $30 \mathrm{~min}$ in a shaking water bath. The $0.5 \mu \mathrm{mol} / \mathrm{L}$ histidine-biotin containing molten top agar at $45^{\circ} \mathrm{C}$ was added to a test tube and the mixture was prepared by rotating it. The mixture was then poured onto a 30-ml Nogel-Bonner plate and the overlay agar was set at room temperature. After that, the plates were incubated in dark at $37{ }^{\circ} \mathrm{C}$ for $48 \mathrm{~h}$. The reverting colonies per plate were calculated and the toxic effects were examined under a stereo-microscope. TA100 was initially used to evaluate the extracts of the pooled samples. A positive control of $2.5 \mu \mathrm{g}$ per plate was used in the absence of S9. The reverting colonies in each of the differ cut samples were counted as the mean of six plates.

\subsection{Measurement of in vivo toxicity}

Male and female Sprague-Dawley rats $(200$
$250 \mathrm{~g}$ ) were treated with sterile PM extract by intratracheal instillation (Toya et al., 2001; Nishi et al., 2009). This study was approved by the Animal Ethics Committee of Khon Kaen University, based on the Ethics of Animal Experimentation of National Research Council of Thailand. Fifteen male rats and fifteen female rats were divided into five groups. Each group ( $n=6)$ was treated as follows:

Group 1: negative control, treated with $0.5 \mathrm{ml}$ of $0.1 \%$ DMSO;

Group 2: positive control, treated with $0.5 \mathrm{ml}$ of $0.1 \% \mathrm{DMSO}+5 \mu \mathrm{g}$ of AF-2 [2-(2-furyl)-3-(5-nitro2-furyl)acrylamide];

Group 3: treated with $0.5 \mathrm{ml}$ of $0.1 \%$ DMSO+ $10 \mu \mathrm{g}$ of PM;

Group 4: treated with $0.5 \mathrm{ml}$ of $0.1 \%$ DMSO+ $100 \mu \mathrm{g}$ of PM;

Group 5: treated with $0.5 \mathrm{ml}$ of $0.1 \%$ DMSO+ $350 \mu \mathrm{g}$ of PM.

\subsection{Intra-tracheal instillation procedure}

The PM was suspended in DMSO at a concentration of 10,100 , or $350 \mu \mathrm{g}$ in $0.5 \mathrm{ml}$, and shaken rigorously with a vortex mixer for $30 \mathrm{~s}$. Both male and female rats received the PM-suspended solution by gentle intra-tracheal instillation (Toya et al., 2001; Nishi et al., 2009). An aliquot of the suspension of $0.5 \mathrm{ml}$, together with $0.5 \mathrm{ml}$ of air, was injected by passing a blunt 18 gauge needle about $50-\mathrm{mm}$ long through the soft palate and vocal cords into the trachea lumen. Animals receiving DMSO of $0.5 \mathrm{ml}$ and air of $0.5 \mathrm{ml}$ were used as a negative control. A wheezing sound of respiration detected with a stethoscope ensured the delivery and good distribution of the instilled particles into the lungs. After $3 \mathrm{~d}$ of instillation, the rats were sacrificed by cervical dislocation and then the lungs were examined for gross lesions and for routine histopathology.

\section{Results}

\subsection{PM levels in the air of ceramic factories in Lampang}

Monthly averages of $8 \mathrm{~h} \mathrm{PM}$ levels observed at six ceramic factories in Lampang were varying among the different departments (Table 1). The lowest mean level of PMs was $33.22 \mu \mathrm{g} / \mathrm{m}^{3}$ (factory D) 
and the highest mean level of PMs was $193.16 \mu \mathrm{g} / \mathrm{m}^{3}$ (factory E). PM levels of factory D were low in all of the departments, whereas they were high everywhere in factory E. PMs are light and they can spread out through all working areas where no partitions were present between departments. All the ceramic factories in Lampang are separated into two parts, office and production areas. PMs or dusts usually overspread in the production areas. A good ventilation system is usually very helpful to force PM out of the factories.

Table 1 Eight-hour average PM concentrations in the air of six ceramic factories (A-F) from each department in Lampang Province, Thailand

\begin{tabular}{|c|c|c|c|c|c|c|}
\hline \multirow{2}{*}{$\begin{array}{c}\text { Department } \\
\text { in factory }\end{array}$} & \multicolumn{6}{|c|}{ Level of 8 -h average PM $\left(\mu \mathrm{g} / \mathrm{m}^{3}\right)$} \\
\hline & $\mathrm{A}$ & $\mathrm{B}$ & $\mathrm{C}$ & $\mathrm{D}$ & $\mathrm{E}$ & $\mathrm{F}$ \\
\hline $\begin{array}{l}\text { Kaolin } \\
\text { preparation }\end{array}$ & 52 & - & 127 & - & 71 & 100 \\
\hline Scraping & 24 & - & - & - & - & - \\
\hline Coating & 40 & 149 & 109 & 31 & 128 & - \\
\hline $\begin{array}{l}\text { Raw material } \\
\text { preparation }\end{array}$ & - & 192 & - & - & - & - \\
\hline Shaping & - & 144 & 171 & 43 & 523 & 121 \\
\hline Casting & - & 125 & 132 & 48 & - & - \\
\hline Rinsing & - & 93 & - & 37 & - & - \\
\hline Decorating & - & 130 & 147 & 29 & - & - \\
\hline Biscuit & - & 95 & 96 & 27 & - & - \\
\hline $\begin{array}{l}\text { Quality } \\
\text { control }\end{array}$ & - & 107 & - & - & - & - \\
\hline Grading & - & 159 & - & 53 & 120 & 195 \\
\hline Packaging & - & 99 & 43 & - & - & - \\
\hline Hallways & - & 181 & 73 & - & - & 91 \\
\hline Assembling & - & - & 141 & - & - & - \\
\hline Painting & - & - & 63 & - & 186 & 153 \\
\hline Firing & - & - & 45 & - & 131 & 84 \\
\hline Stickering & - & - & 110 & 27 & - & - \\
\hline Engineering & - & - & 138 & - & - & - \\
\hline Stocking & - & - & - & 4 & - & - \\
\hline Mean & 38.6 & 134.00 & 107.3 & 33.22 & 193.16 & 124.00 \\
\hline
\end{tabular}

\subsection{Elemental composition in PM extracts col- lected from ceramic factory}

Using ICP-MS, the following chemical elements were detected at lower concentrations: lead $(209.89 \mathrm{mg} / \mathrm{kg})$, copper $(189.80 \mathrm{mg} / \mathrm{kg})$, nickel (43.85 mg/kg), chromium (39.49 mg/kg), cadmium $(17.92 \mathrm{mg} / \mathrm{kg})$, arsenic $(16.42 \mathrm{mg} / \mathrm{kg})$, and selenium $(0.32 \mathrm{mg} / \mathrm{kg})$. Using the ICP-OES, the following chemical elements were detected at higher concentrations: sodium $(14.82 \mathrm{~g} / \mathrm{kg})$, calcium $(10.969 \mathrm{~g} / \mathrm{kg})$, potassium $(7.53 \mathrm{~g} / \mathrm{kg})$, iron $(3.99 \mathrm{~g} / \mathrm{kg})$, zinc $(0.97 \mathrm{~g} / \mathrm{kg})$, magnesium $(0.62 \mathrm{~g} / \mathrm{kg})$, and manganese $(0.34 \mathrm{~g} / \mathrm{kg})$.

\subsection{Mutagenicity trends}

Dichloromethane extracts of PMs collected from six ceramic factories were not mutagenic to the Salmonella typhimurium strain TA 100 with S9 mix activation. As shown in Table 2, the revertant colonies of TA 100 per plate, when adding PM extracts, were not different from that when adding DMSO (negative control).

\subsection{Effect of PM on rats' lungs}

There was no difference in the wheezing sound of respiration observed between the negative control and PM-treated groups during the 3-d treatment. This indicates that the PMs do not have an acute toxicity in the respiratory system of rats.

After sacrifice, we observed gross lesions in the lungs of both the male and female rats of the positive control group, and groups treated with PMs. We noticed that the distribution of lesions in the $350 \mu \mathrm{g}$ PM-treated group was much less severe than that in the positive control group. The lesions consist of the reduction of alveolar ducts and sacs and the thickening of pulmonary interstitial tissues (Figs. 1a, 1d, 1e,

Table 2 Mutagenicity of extract from PM samples collected at six ceramic factories (A-F)

\begin{tabular}{lcccccc}
\hline \multirow{2}{*}{ Treatment } & \multicolumn{6}{c}{ Revertant colony of TA 100 per plate $(n=6)$} \\
\cline { 2 - 7 } & $\mathrm{A}$ & $\mathrm{B}$ & $\mathrm{C}$ & $\mathrm{D}$ & $\mathrm{E}$ & $\mathrm{F}$ \\
\hline DMSO (negative control) & $14 \pm 3$ & $32 \pm 4$ & $32 \pm 2$ & $33 \pm 3$ & $33 \pm 4$ & $23 \pm 3$ \\
$\mathrm{AF}-2$ (positive control) & $232 \pm 13$ & $392 \pm 10$ & $392 \pm 11$ & $263 \pm 9$ & $263 \pm 10$ & $212 \pm 12$ \\
PM extract $10 \mu \mathrm{g}$ & $18 \pm 6$ & $43 \pm 8$ & $33 \pm 7$ & $32 \pm 4$ & $29 \pm 6$ & $21 \pm 5$ \\
PM extract $100 \mu \mathrm{g}$ & $23 \pm 4$ & $42 \pm 10$ & $35 \pm 6$ & $39 \pm 7$ & $31 \pm 3$ & $14 \pm 4$ \\
PM extract $350 \mu \mathrm{g}$ & $14 \pm 5$ & $33 \pm 9$ & $30 \pm 5$ & $18 \pm 8$ & $22 \pm 5$ & $39 \pm 3$ \\
\hline
\end{tabular}

AF-2: 2-(2-furyl)-3-(5-nitro-2-furyl)acrylamide 
1h, 1i, and $1 \mathrm{j}$ ) compared with the control (Figs. 1a and $1 \mathrm{f}$ ). In addition, the lung tissue of the positive control group of male rats was seriously damaged (Figs. 1b and $1 \mathrm{~g}$ ) compared to that of the negative control group in the histology by hematoxylin-eosin (H\&E) staining, indicating reliability and consistency of our intra-tracheal instillation technique. In male rats, the lung tissues appeared to be normal in the $10 \mu \mathrm{g}$ PM-treated group (Figs. 1c and 1h); they started to be damaged in the $100 \mu \mathrm{g}$ (Figs. 1d and 1i) and were worse in the $350 \mu \mathrm{g}$ PM-treated groups (Figs. 1e and 1j).

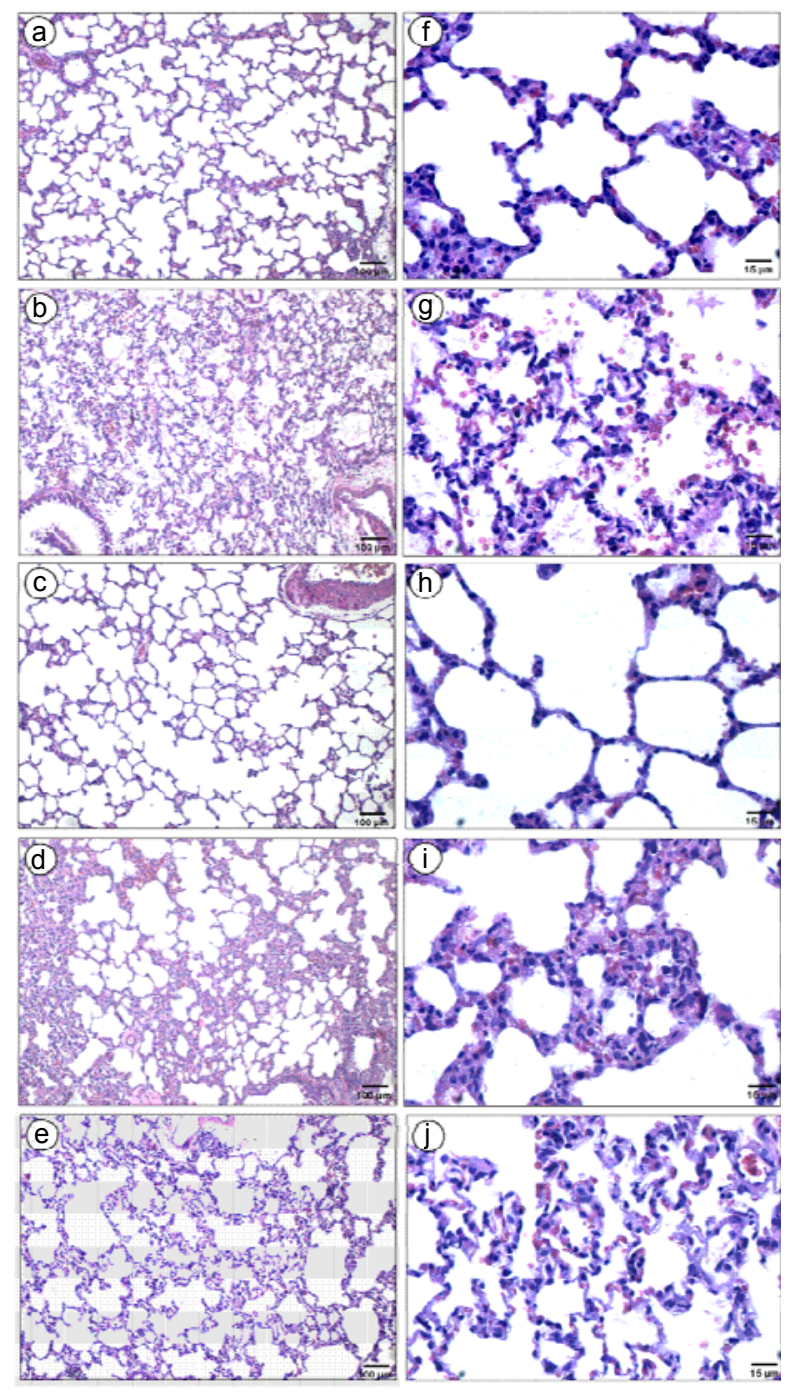

Fig. 1 Histology of male rat lungs $(n=10)$ stained with hematoxylin-eosin (H\&E)

(a, f) Negative control; (b, g) Positive control; (c, h) PM $10 \mu \mathrm{g}$; (d, i) PM $100 \mu \mathrm{g}$; (e, j) PM $350 \mu \mathrm{g}$
In female rats, the lung tissues were injured by $10 \mu \mathrm{g}$ of PM treatments (Figs. $2 \mathrm{~b}$ and $2 \mathrm{f}$ ) compared to the negative control group (Figs. 2a and 2e) and were more severe in $100 \mu \mathrm{g}$ (Figs. 2c and $2 \mathrm{~g}$ ) and $350 \mu \mathrm{g}$ (Figs. 2d and 2h) PM-treated groups.

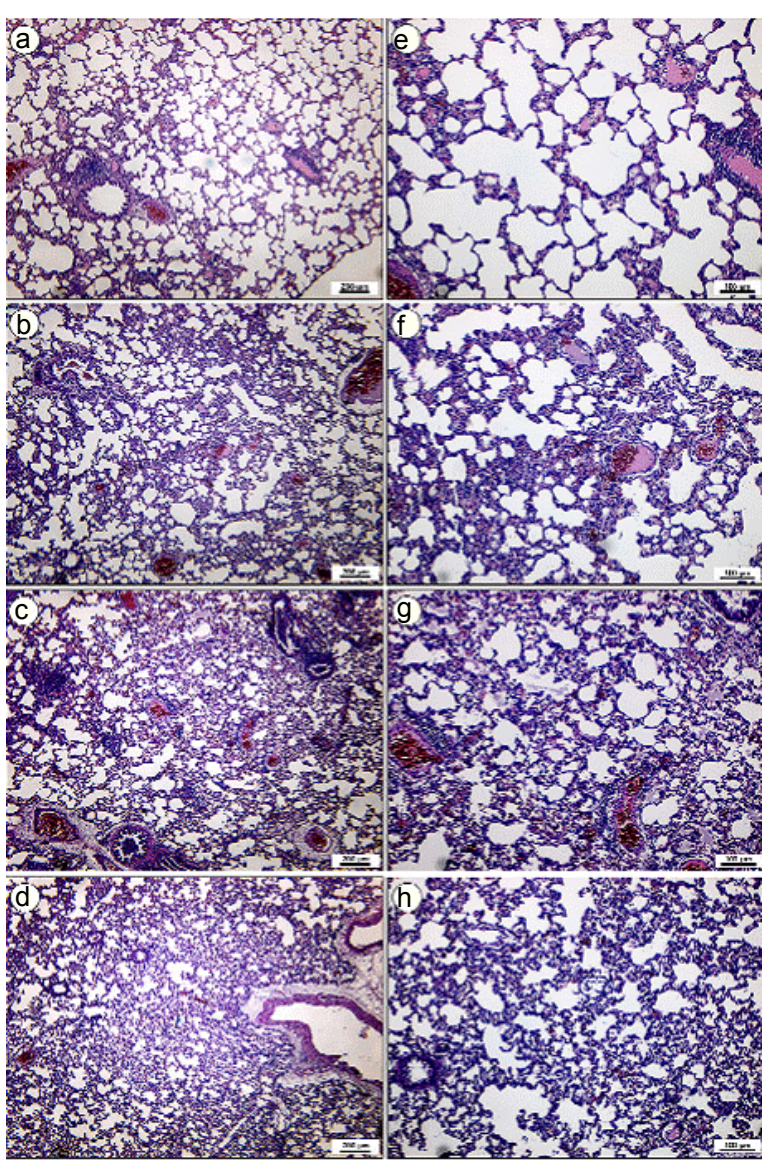

Fig. 2 Histology of female rat lungs $(n=10)$ stained with hematoxylin-eosin (H\&E)

(a, e) Negative control; (b, f) PM $10 \mu$ g; (c, g) PM $100 \mu$ g; (d, h) PM $350 \mu \mathrm{g}$

\section{Discussion}

This study measured the level of PMs in working areas of six ceramic factories in Lampang Province, Thailand. Results of the measurement showed that the mean values of 8 -h average PM levels from six factories ranged from 33.22 to $193.17 \mu \mathrm{g} / \mathrm{m}^{3}$ (Table 1). The level of PMs depended on structure, ventilation, and the different departments of the factories including the season of the collecting period. A 
lot of departments in the factories exhibited relatively high concentration $\left(>100 \mu \mathrm{g} / \mathrm{m}^{3}\right.$; Table 1) of PMs, e.g., shaping, grading, casting, coating, and decorating departments. Factory A had a low level of PMs in all their three departments $\left(55 \mu \mathrm{g} / \mathrm{m}^{3}\right.$ or less). However, we were not allowed to collect PMs in other areas of this factory; therefore, we cannot give the reason for this event. Factory D also had a low level of PMs $\left(<55 \mu \mathrm{g} / \mathrm{m}^{3}\right)$ in all of their departments because the PMs were collected during the rainy season (September), in which the humidity is the highest of the year. Moreover, there were many air blowers on the roof to help the ventilation although factory D (PMs can spread to every part of the factory) had no partition between various departments. Factory E showed the highest mean level of PMs because PM level was very high in the shaping area $\left(523 \mu \mathrm{g} / \mathrm{m}^{3}\right)$. In addition, the PM level in every department of factory $\mathrm{E}$ tended to be higher than the other factories. It is observed that this factory had a really closed circulation system, there were no windows and the ventilation inside the factory was not very good at all. Factories B, C, and F had no difference in their PM levels although they were different in their sizes. In this study, the results demonstrated that monthly average 8-h samples of PMs taken from four out of the six ceramic factories were higher than $100 \mu \mathrm{g} / \mathrm{m}^{3}$.

Exposure to PMs especially PM2.5 and PM10 can increase the risk of respiratory health problems with both short-term and long-term effects (Baccini et al., 2011; Cakmak et al., 2012; Hampel et al., 2012; Salam et al., 2012). To prevent workers from inhaling high amounts of PMs, wearing masks are strongly recommended during working hours. In addition, natural air ventilation can help to reduce these PM levels. Therefore, factory owners should be concerned and take responsibility to safeguard their employees.

In the elemental analysis of PM, two groups of elements were identified which belong to the high and low concentrations of chemical elements, respectively. Among the high-concentration group, iron is the most interesting one. Iron plays a crucial role in various metabolic processes. However, there is some evidence for the carcinogenicity of iron that this metal possibly triggers hydroxyl radical formation which leads to DNA damage (Gu et al., 2011;
Vijayavel et al., 2012). Since the concentration of iron is very high in PM extracts (about $3800 \mathrm{mg} / \mathrm{kg}$ ), the breathing in of PM-contaminated air needs to be strictly controlled.

Among the low-concentration group, a lot of heavy metals were detected in PM extracts. Although the levels of heavy metals were low in units of milligram per kilogram, these metals are known to play roles in carcinogenesis (Yang, 2011; MartinezZamudio and Ha, 2011). Lead was high in this group and it can lead to the cancers of stomach, intestine, renal, lung, and myeloma and leukemia (van Bemmel et al., 2011; Ilychova and Zaridze, 2012). Cadmium is known to be a mutagen in mammalian, causing DNA damage, and can be associated with cancers of prostate, renal, and lung (Li et al., 2011; Luo et al., 2011; Osipov et al., 2011; Adams et al., 2012). The other two metals which are known to relate to the development of cancers especially the speed-up of tumor growth are chromium and zinc (Rudolf and Cervinka, 2006; Beyersmann and Hartwig, 2008; Chadha et al., 2010; Gumulec et al., 2011). In humans, these metals have been associated with a more rapid progression of cancers of breast, colon, rectum, ovary, lung, pancreas, bladder, and leukemia (Franklin and Costello, 2009; Galanis et al., 2009; Chadha et al., 2010).

In fact, not all heavy metals are toxic and not all toxic heavy metals have the same toxicity. Therefore, many countries differentiate heavy metals into three classes by ranking their toxicity levels. This study revealed heavy metals of the three classes, i.e., class I: cadmium; class II: arsenic, nickel, and selenium; and, class III: lead, chromium, copper, and manganese. The heavy metal of class I is most toxic and harmful, whereas the ones of class III are least toxic. In the present finding, PM extracts had higher cadmium concentration $(17 \mathrm{mg} / \mathrm{kg})$ than the World Health Organization (WHO) annual average guideline $(5 \mathrm{ng} / \mathrm{kg})$. Moreover, chromium concentrations in all samples $(39 \mathrm{mg} / \mathrm{kg}$ ) were higher than $2.5 \mathrm{ng} / \mathrm{kg}$ of the WHO guideline, which corresponds to an excess of lifetime risk of 1:10000 (WHO, 2000). The metals found in the PM extracts may come from raw materials used in ceramic factories. Therefore, it is necessary to measure and control the amount of chemical elements in raw materials for the workers, helping to avoid carcinogen exposure. 
PMs collected from the different factories contain condensed organic matters that are extractable by organic solvents (Vinitketkumnuen et al., 2002). A number of studies have shown that the organic extractable matters from air particles and different combustion sources are carcinogenic in animals (Hueper et al., 1962) and mutagenic in short-term bioassay tests (Alfheim et al., 1983). However, our results showed that dichloromethane extracts of PMs, collected in ceramic factories, were not mutagenic to S. typhimurium strain TA 100 with metabolic (S9 mix) activation as compared to the positive control. The metabolic activation (S9) is a biotransformation of relatively inert chemicals to high metabolites with numerous chemically induced toxicities (Patricia, 1994). However, this experiment was done in the bacterial model, and there are more complicated processes in an in vivo system.

The present findings indicate that PM at a high dose $(350 \mu \mathrm{g})$ damages the lung of both male and female rats (Figs. 1 and 2). However, PM at a lower amount $(10 \mu \mathrm{g})$ does not affect the lung in the histology of a male rat, whereas PM at dosages of $100 \mu \mathrm{g}$ starts to affect it. In contrast, the lungs of the female rats started to be damaged with PM at dosages of $10 \mu \mathrm{g}$ and its damage was more severe at $350 \mu \mathrm{g}$ PMs (Fig. 2). Therefore, this lung response was attenuated in male rats. These findings indicate that sexes may be correlated with the level of lung damage by intra-tracheal instillation of PMs. It has been reported that intranasal instillation of fine PM $(2.5 \mu \mathrm{m})$ can induce acute lung inflammation in mice (Riva et al., 2011). In addition, Budinger et al. (2011) revealed severe lung damage in mice which received ambient PMs via intra-tracheal instillation. Obviously, the present study also demonstrated in rats that ceramic PMs induced histological changes of lung tissues, which consist of the reduction of alveolar duct and sac spaces, and increased interstitial connective tissues (alveolar septa) as compared to the normal control lung tissues (Figs. 1 and 2). Taken all together, the present study clarified that PMs can primarily induce the histological changes of rodent lungs. Since the expressions of some cancer markers have been reported in the lung tissue receiving PMs (Laskin et al., 2010; Budinger et al., 2011; Riva et al., 2011), it is necessary to examine the effects of ceramic PM on the expression of lung cancer mark- ers as the next step.

In conclusion, although PM extracts consist of high amounts of iron and a detectable amount of lead, cadmium, chromium, and zinc, they are not mutagenic for S. typhimurium strain TA 100. In rats, the induction effect of ceramic PMs on histological changes of the lung tissues is more sensitive in females than in males. These structural changes may imply the possibility of PM-induced lung cancer whose mechanism remains to be elucidated. Importantly, ceramic industries must seriously take note of the necessity for different ways to protect employees from the risk of high PM inhalation.

\section{Acknowledgements}

We would like to thank Dr. Thiravud KUHAPREMA, Director of National Cancer Center, Thialand, for his efforts in research funding, and the Lampang Provincial Labor Protection and Welfare Office for their cooperations in the PM collection process. We would also like to thank Prof. Hisatake KONDO, overseas visiting professor of the Anatomy Department, Faculty of Medicine, Khon Kaen University, Thialand, for proofreading through this article.

\section{Compliance with ethics guidelines}

Duriya FONGMOON, Surathat PONGNIKORN, Aphiruk CHAISENA, and Sitthichai IAMSAARD declare that they have no conflict of interest.

All institutional and national guidelines for the care and use of laboratory animals were followed.

\section{References}

Adams, S.V., Passarelli, M.N., Newcomb, P.A., 2012. Cadmium exposure and cancer mortality in the Thrid National Health and Nutrition Examination Survey cohort. Occup. Environ. Med., 69(2):153-156. [doi:10.1136/ oemed-2011-100111]

Alfheim, I., Löfroth, G., Møller, M., 1983. Bioassay of extracts of ambient particulate matter. Environ. Health Perspect., 47:227-238.

Baccini, M., Biggeri, A., Grillo, P., et al., 2011. Health impact assessment of fine particle pollution at the regional level. Am. J. Epidemiol, 174(12):1396-1405. [doi:10. 1093/aje/kwr256]

Beyersmann, D., Hartwig, A., 2008. Carcinogenic metal compounds: recent insight into molecular and cellular mechanisms. Arch. Toxicol., 82(8):493-512. [doi:10. 1007/s00204-008-0313-y]

Budinger, G.R., McKell, J.L., Urich, D., et al., 2011. Particulate matter-induced lung inflammation increases systemic levels of PAI-1 and activates coagulation through 
distinct mechanisms. PLoS ONE, 6(4):e18525. [doi:10. 1371/journal.pone.0018525]

Cakmak, S., Dales, R.E., Coates, F., 2012. Does air pollution increase the effect of aeroallergens on hospitalization for asthma? J. Allergy Clin. Immunol., 129(1):228-231. [doi:10.1016/j.jaci.2011.09.025]

Chadha, V.D., Gerg, M.L., Dhawan, D., 2010. Influence of extraneous supplementation of zinc on trace elemental profile leading to prevention of dimethylhydrazineinduced colon carcinogenesis. Toxicol. Mech. Meth., 20(8):493-497. [doi:10.3109/15376516.2010.511300]

Franklin, R.B., Costello, L.C., 2009. The important role of the apoptotic effects of zinc in the development of cancers. J. Cell. Biochem., 106(5):750-757. [doi:10.1002/jcb. 22049]

Galanis, A., Karapetsas, A., Sandaltzopoulos, R., 2009. Metal-induced carcinogenesis, oxidative stress and hypoxia signaling. Mutat. Res./Genet. Toxicol. Environ. Mutagen., 674(1-2):31-35. [doi:10.1016/j.mrgentox. 2008.10.008]

Gu, Y., Hua, Y., He, Y., et al., 2011. Iron accumulation and DNA damage in a pig model of intracerebral hemorrhage. Acta Neurochir. Suppl., 111:123-128. [doi:10. 1007/978-3-7091-0693-8_20]

Gumulec, J., Masarík, M., Krízková, S., et al., 2011. Molecular mechanisms of zinc in prostate cancer. Klin. Onkol., 24(4):249-255.

Hampel, R., Breitner, S., Schneider, A., et al., 2012. Acute air pollution effects on heart rate variability are modified by SNPs involved in cardiac rhythm in individuals with diabetes or impaired glucose tolerance. Environ. Res., 112:177-185. [doi:10.1016/j.envres.2011.10.007]

Hueper, W.C., Kolin, P., Tabor, E.C., et al., 1962. Carcinogenic bioassays on air pollutants. Arch. Pathol., 74: 89-116.

Ilychova, S.A., Zaridze, D.G., 2012. Cancer mortality among female and male workers occupationally exposed to inorganic lead in the printing industry. Occup. Environ. Med., 69(2):87-92. [doi:10.1136/oem.2011.065201]

Laskin, D.L., Mainelis, G., Turpin, B.J., et al., 2010. Pulmonary effects of inhaled diesel exhaust in young and old mice: a pilot project. Res. Rep. Health Eff. Inst., 151:3-31.

Lauer, F.T., Mitchell, L.A., Bedrick, E., et al., 2009. Temporalspatial analysis of U.S.-Mexico border environmental fine and coarse PM air sample extract activity in human bronchial epithelial cells. Toxicol. Appl. Pharmacol., 238(1):1-10. [doi:10.1016/j.taap.2009.04.021]

Li, R., Yuan, C., Dong, C., et al., 2011. In vivo antioxidative effect of isoquercitrin on cadmium-induced oxidative damage to mouse liver and kidney. Naunyn-Schmiedebergs Arch. Pharmacol., 383(5):437-445. [doi:10.1007/s00210011-0613-2]

Luo, J., Hendryx, M., Ducatman, A., 2011. Association between six environmental chemicals and lung cancer incidence in the United States. J. Environ. Public Health,
2011:463701. [doi:10.1155/2011/463701]

Mantecca, P., Farina, F., Moschini, E., et al., 2010. Comparative acute lung inflammation induced by atmospheric PM and size-fractionated tire particles. Toxicol. Lett., 198(2):244-254. [doi:10.1016/j.toxlet.2010.07.002]

Maron, D.M., Ames, B.N., 1983. Revised methods for the Salmonella mutagenicity test. Mutat. Res./Environ. Mutagen. Relat. Subj., 113(3-4):173-215. [doi:10.1016/ 0165-1161(83)90010-9]

Martinez-Zamudio, R., Ha, H.C., 2011. Environmental epigenetics in metal exposure. Epigenetics, 6(7):820-827. [doi:10.4161/epi.6.7.16250]

Nishi, K., Morimoto, Y., Ogami, A., et al., 2009. Expression of cytokine-induced neutrophil chemoattractant in rat lungs by intratracheal instillation of nickel oxide nanoparticles. Inhal. Toxicol., 21(12):1030-1039. [doi:10. 1080/08958370802716722]

Osipov, A.N., Riabchenko, N.I., Ivannik, B.P., et al., 2011. DNA damage in thymocytes of mice under combined acute whole body exposure to cadmium ions and gamma-radiation. Radiats Biol. Radioecol., 51(3): 315-320.

Patricia, E.L., 1994. Reactive metabolites and toxicity. In: Hodgson, E., Smart, R.C. (Eds.), Introduction to Biochemical Toxicology. Appleton \& Lange, Norwalk, Conn., p.219.

Raunroadroong, N., Daoprasert, K., Srisukho, S., et al., 2009. Cancer Incidence in Northern Thailand 2003-2007. Lampang Cancer Center, p.10-29.

Riva, D.R., Magalhaes, C.B., Lopes, A.A., et al., 2011. Low dose of fine particulate matter (PM2.5) can induce acute oxidative stress inflammation and pulmonary impairment in healthy mice. Inhal. Toxicol., 23(5):257-267. [doi:10.3109/08958378.2011.566290]

Rudolf, E., Cervinka, M., 2006. The role of intracellular zinc in chromium(VI)-induced oxidative stress, DNA damage and apoptosis. Chem. Biol. Interact., 162(3):212-227. [doi:10.1016/j.cbi.2006.06.005]

Salam, M.T., Byun, H.M., Lurmann, F., et al., 2012. Genetic and epigenetic variations in inducible nitric oxide synthase promoter particulate pollution and exhaled nitric oxide levels in children. J. Allergy Clin. Immunol., 129(1):232-239. [doi:10.1016/j.jaci.2011.09.037]

Tokiwa, H., Horikawa, K., Sera, N., 1992. Influence for the microsomal inducer and the incubation system on mutagenicity of complex mixtures. Mutat. Res./Rev. Genet. Toxicol., 276(1-2):139-144. [doi:10.1016/0165-1110 (92) $90063-\mathrm{F}]$

Toya, T., Fukuda, K., Takaya, M., et al., 2001. Lung lesions induced by intratracheal instillation of vanadium pentoxide powder in rats. Ind. Health, 39(1):8-15. [doi:10.2486/indhealth.39.8]

van Bemmel, D.M., Boffetta, P., Liao, L.M., et al., 2011. Comprehensive analysis of 5-aminolevulinic acid dehydrogenase (ALAD) variants and renal cell carcinoma risk among individuals exposed to lead. PLOS ONE, 
6(7):e20432. [doi:10.1371/journal.pone.0020432]

Vijayavel, K., Downs, C.A., Ostrander, G.K., et al., 2012. Oxidative DNA damage induced by iron chloride in the larvae of the lace coral Pocillopora damicornis. Comp. Biochem. Physiol. C Toxicol. Pharmacol., 155(2): 275-280. [doi:10.1016/j.cbpc.2011.09.007]

Vinitketkumnuen, U., Kalayanamitra, K., Chewonarin, T., et al., 2002. Particulate matter PM 10 \& PM 2.5 levels and airborne mutagenicity in Chiang Mai Thailand. Mutat.
Res./Genet. Toxicol. Environ. Mutagen., 519(1-2): 121-131. [doi:10.1016/S1383-5718(02)00130-4]

World Health Organization (WHO), 2000. Air Quality Guidelines for Europe, 2nd Edition. WHO Regional Publications, European Serials, No. 91.

Yang, M., 2011. A current global view of environmental and occupational cancers. J. Environ. Sci. Health C Environ. Carcinog. Ecotoxicol. Rev., 29(3):223-249. [doi:10. 1080/10590501.2011.601848]

\section{中文梅要：}

\section{本文题目：泰国南邦省陶瓷厂细颗粒物对大鼠肺部的影响}

Particulate matters collected from ceramic factories in Lampang Province affecting rat lungs

研究目的：研究泰国南邦省陶瓷厂细颗粒物对基因突变和大鼠肺部的影响。

创新要点: 探究泰国北部肺癌高发的一个重要诱因可能是当地高度发达的陶瓷工业产生细颗粒物所引起。

研究方法: 使用二甲基亚砜 (DMSO) 提取泰国南邦省六家陶瓷厂空气中的收集到的细颗粒物。采用电感 耦合等离子体质谱 (ICP-MS) 和电感耦合等离子体光学发射光谱 (ICP-OES) 来分别分析细 颗粒物中的低浓度和高浓度的化学元素, 然后采用污染物致突变性检测 (Ames 试验) 对细颗 粒物的致基因突变能力进行研究, 最后采用组织学分析了细颗粒物对大鼠肺部的影响。

重要结论: 陶瓷厂空气中的细颗粒物不会导致鼠伤寒沙门氏菌的基因突变, 但是能引起大鼠肺部损伤, 且雌性大鼠对由空气中细颗粒物引起的肺部损伤更为敏感。

关键词组: 细颗粒物; 陶瓷厂; 泰国南邦省; 大鼠肺部 